\title{
Categories of Hegemonic Discourse in Contemporary China
}

\author{
Xinfa Yuan', Jiuquan Han² \\ ${ }^{1}$ Foreign Language Department, Baoding University, Baoding, China \\ ${ }^{2}$ College of Foreign Language, Hebei Agricultural University, Baoding, China \\ Email: yuanxinfa66@163.com
}

Received 17 March 2015; accepted 5 April 2015; published 8 April 2015

Copyright (C) 2015 by authors and Scientific Research Publishing Inc.

This work is licensed under the Creative Commons Attribution International License (CC BY).

http://creativecommons.org/licenses/by/4.0/

(c) (i) Open Access

\begin{abstract}
Following the principles of rhetorical political approach and discourse-historic approach, this paper discusses the categories of how implicit hegemonic discourse (IHD) manipulators in contemporary China discursively justify their own special interests and mislead the dominated to "maintain consent" to the current hegemony pernicious to the future of Chinese civilization. And it is concluded that the collusion between corrupted officials, pirate businessmen and their patronized scholars is getting more and more solid and prominent. Therefore more hegemonic discourses would appear until an end is put by the practice of ruling the nation by law.
\end{abstract}

\section{Keywords}

Implicit Hegemonic Discourse, Rhetorical Political Approach, Categories, Contemporary China

\section{Introduction}

The meaning of hegemony has gone several changes since its birth. Its etymological origin dates back to ancient Greece, hegemony which denoted the politico-military dominance of a city-state over other city-states (Bullock \& Trombley, 1999: 387-388). In the 19th century, hegemony denoted the geopolitical and the cultural predominance of one country upon others, from which derived hegemonism, the Great Power politics meant to establish European hegemony upon continental Asia and Africa (Bullock \& Trombley, 1999: 387-388). In the 20th century, Antonio Gramsci developed philosophy and sociology of geopolitical hegemony into the theory of Cultural Hegemony, whereby one social class could manipulate the system of values and mores of a society, in order to create and establish a ruling-class, a worldview that justified the status quo of bourgeois domination of the other social classes of the society (Chernow \& Vallasi, 1994: 1215).

Based on the theories above, it is reasonable for the author to infer the following points: 1) As lingui-cultural 
hegemony is indirect, implicit hegemonic discourses (thereafter IHD) are much less distinctive thus more difficult to be perceived by the hearer; 2) These hegemonic discourses may be employed directly by the government officials or indirectly by powerful individuals as representatives in the name of businessmen or that of scholars.

Nowadays, implicit hegemonic discourses (IHD) in contemporary China tend to get more and more severe. In order to have a deeper understanding of IHD, this paper discusses the categories of implicit hegemonic discourse (IHD), which includes 1) framing another coordinate system, 2) employing double standards, 3) miscoloring, and 4) inciting false propositions.

\section{Setting up Data Collection Standard}

According to Piñuel \& Gaitán (2010), the daily discourse is ideal for data collection because it facilitates the task of revealing the production of social discursive communication. The repetitive presence of a certain discourse allows obtaining stereotyped images, which are often mirrored in a "text" "as a specific and unique realization of a discourse” (Glynos, Howarth et al., 2009: 19).

Therefore, the author sets up the standard of data collection as follows:

1) Source: In this paper, all discourses come from official media or those with heavy official color which are quite influential in the domain of Chinese language, at least on the mainland. 2) Influence: the selected IHDs are widely spread and heatedly discussed through various channels, especially on the internet. 3) Agents: the manipulators of analyzed IHD refer to those officials at various levels, representatives of conglomerates and their patronized scholars who enjoy both national wealth and super discursive power. 4) Modes: the IHD manipulators employ, consciously or unconsciously, some pragmatic tricks to create logical specters as to mislead the disadvantaged.

\section{Categorizing the Selected Data}

Rhetorical political approach (RPA) concerns the arrangement of a political narrative with three modes of rhetorical appeal: logos-centric, ethos-centric and pathos-centric (Finlayson, 2007: 558; Gottweis, 2006: 243). In politics, logos-centric argumentation relies not on syllogisms but on enthymemes or quasi-logical arguments. Ethos-centric argumentation relies on the speaker's charisma or authority, expertise, experience or qualifications to address a particular issue. Pathos-centric argumentation concerns empathy, sympathy and sensibilities.

In this paper, the author discovers that IHD manipulators appeal to either false premises or authoritative positions and consequently lead to slippery slopes in logic, and to nowhere in content.

\subsection{Framing another Coordinate System}

The first category of IHD is made logos-centrically by framing another coordinate system. In this case, an HDM (hegemonic discourse manipulator) may openly or stealthily give a new definition of a well-established concept to provide a plausible major premise for a further syllogism. Once induced into this new frame, the hearer is sure to lose his/her original criteria and reach a wrong conclusion.

Look at an example from one of Top 10 News Stories in the year of 2010. Tang Jun, a billionaire of IT, claimed proudly that he was graduated from California Institute of Technology with a $\mathrm{PhD}$ degree of Computer Science. Fang (2010) exposed that Tang had bought a PhD degree from Western Pacific University (USA) and faked his resume. In defending from Fang's challenge, Tang played a discursive trick-framing another coordinate system:

Reporter: Is honesty an essential factor for success?

Tang: Of course. It is quite hard to be successful if not honest. Surely you cannot succeed at all if not honest. Some people complain that there are so many liars in this world. For me, a person who can deceive only one person deserves being called a liar. That's no question. If you can cheat, however, all the world, it means that you have beguiled them sincerely, which is a symbol of capability and a sign of success (Shen, 2010).

In order to show that he is not telling a lie, Tang first introduces roles of honesty: sometimes serving as the seemingly essential condition for success ("It is quite hard to be successful if not honest"), sometimes as the necessary prerequisite ("Surely you cannot succeed at all if not honest"). Then, he gives a new definition of "honesty" which is meaningful as long as "all the world has been fooled by you". In his argument, the word 
"deceiving" either means that "cheating a person” is a lying and or that being able to "deceive the world" is "a symbol of capability and a sign of success".

Tang Jun's view of honesty was echoed by Yu Jinyong's (a billionaire of real estate) concept of sincerity (Hua, 2010).

Yu: If a person tells the truth about a certain matter, he is not honest but foolish. Sincerity, in my eyes, is the "perseverance at the bottom of heart" instead of something outside so that each of us at presence has his/her own. Sincerity needs not to be expressed in words or in action since it totally belongs to a person's inner world. My idea of sincerity is sharply different from the conventional one that honesty should be fulfilled in both words and actions, which is so apparent... To sum it up, an action cannot represent your sincerity (Hua, 2010).

In Yu's argument, he redefines sincerity as "perseverance at the bottom of heart", which needs not to be expressed neither in words nor in actions since it totally belongs to a person's himself, it has nothing to do with other's cares. Accordingly, a person "telling the truth" is just a "fool".

In brief, both Tang and Yu want to provide a plausible major premise to mislead the hearers.

\subsection{Employing Double Standards}

Unlike reestablishing a new coordinate system, setting up double standard involves both logos-centric and ethoscentric appeals, namely, the former to stealing the concept or misplacement of argumentative elements and the latter to authority.

Globalization and glocalization, for example, are prevalent at the new age. Proper understanding, interpretation and application of international laws and conventions will enhance a nation's economic, political or cultural improvement. Some state organizations backed by the government, unfortunately, take advantage of their special positions, and of ordinary people's lacking expertise in certain fields to exploit the greatest profit as much as possible.

Petro China and Sinopec, dubbed as "Liang Tong You" (two barrels of oil), used to be notorious for their "acting on international conventions" to uplift oil price when it is rising overseas and infamous for their "adapting the nation's condition" to reject cutting it down when it has already fallen internationally for weeks (Jiao, 2011). First, they turn to the international conventions as if all international conventions are absolutely right for whoever to follow, wherever and whenever; thus, it would be economically, legally and administratively reasonable to keep the earlier price. At this time, cutting down the price would mean going against globalization. Second, they fall back on another authority's (Karl Marx) case-by-case theory to tell the subordinate why it is reasonable to keep the price up when it has fallen down on the international market for days, even weeks. They would argue that conditions in China are too economically and legally complicated, unrealistic, thus, it is plausible to "adapt to the nation's condition" to maintain a high price.

By adroitness in ethos-centric appeal, Liang tong you play well with concepts of globalization and glocalization.

\subsection{Miscoloring}

When the IHD maker finds it hard to cheat participant straightly, he will turn to miscoloring to neutralize those sensitive words by castrating, misinterpreting or isolating laws and regularities, degrading collective behavior into personal, whitening illegal violations into mistakes or errors, or at least, turning substantive unlawfulness into procedural illegalness. Such discourses are both logos-centric and pathos-centric.

When forced to punish an official, for example, the local government of Jianyang City, Sichuan Province, made a precise choice of "transferred" instead of "removed", "exempted", "resigning under the order", "dismissed" or "annulled" to veil the fact that the government had spoiled that official and refused to punish him severely. Choosing this neutral word, according to Sun (2010), has at least three impacts: 1) showing that the official concerned has been severely punished; 2) leaving a hint foreshadowing fresh employment; 3) removing the officials concerned from outside pressure.

In this way, the local government wins a pathos-centric appeal by calling for others' sympathy for the punished official. 


\subsection{Inciting False Proposition}

Lastly, IHD manipulators tend to incite a false proposition by expounding it as true.

One of most prevalent proposition that "nothing is more precious than a man's life", for instance, is true if a person's life is threatened by disasters or accidents. When de-contextualized, however, it may turn into a false proposition.

In order to save those heavily corrupt officials from being sentenced to death, Liu (2010), a famous legal scholar at China Social Science Academy, firstly de-contextualizes the proposition, in which he adroitly intermingles the "life" in a disaster or a kidnapping with that in a corruption crime. In this way, Liu manages to argue for the abolishment of death penalty against corrupt officials.

Unlike the argument for the first false proposition where he makes use of logos-centric appeal, Liu (2010) chiefly takes advantage of pathos-centric appeal in the second argument for another false proposition that "a statesman should follow his own principle rather than the will of people because people's will should be piloted rather than succumbed".

In this proposition, Liu simply managed to inject the following propositions into the hearers as major premise for a further syllogism: 1) statesmen are elites while the public are ordinary; 2) anything of the former is superior to that of the latter, including their intelligence and insights; 3) the former is a leader, active; the latter, follower, passive.

These inserted plausible propositions, in spite of their falsity, seem successful in building a bridge for the false proposition to win the officials' empathy that they are superior to the ordinary intellectually, emotionally, and socio-eco-politically.

\section{Conclusion and Implications}

With the development of special interests groups, the collusion between corrupted officials, pirate businessmen and their patronized scholars is getting more and more solid and prominent. It is not rare, consequently, for numerous hegemonic discourses to be made individually or collectively. Recent explicit shocking official discourses were so frequently uttered that a rupture between the government and the public come into being, on one hand (Wang, 2011), the aggregation of hegemonic discourses, on the other hand, catalyzes the process of mal formation of political power and "power-worshipping" culture all over the mainland (Xiao, 2012).

To make it worse, hegemonic falsehood swallows part of public comment rights on many bombshells or sensitive issues. Right or wrong syntactically, a lot of newly created terms, such as "be suicidED", "be volunteerED", "be represented", "be livED in a well-to-do society", become rather epidemic. As the weak, to borrow Marx's (cited in Said, 1977: XXV) words, "(t)hey cannot represent themselves; they must be represented". There arrives the "Passive Age".

More hegemonic discourses would appear until an end is put by the practice of ruling the nation by law.

\section{References}

Bullock, A., \& Trombley, S. (1999). The New Fontana Dictionary of Modern Thought (3rd ed., pp. 387-388). London: Harper Collins.

Chernow, B. A., \& Vallasi, G. A. (Eds.) (1994). The Columbia Encyclopedia (5th ed., p. 1215). New York: Columbia University Press.

Fang, Z. Z. (2010). Faking Credential Gate of Tang Jun, a Hit Work Emperor. http://news.163.com/special/00014IRA/tangjunzaojiamen.html

Finlayson, A. (2007). From Beliefs to Arguments: Interpretive Methodology and Rhetorical Political Analysis. British Journal of Politics and International Relations, 9, 545-563. http://dx.doi.org/10.1111/j.1467-856X.2007.00269.X

Glynos, J., Howarth, D. et al. (2009). Discourse Analysis: Varieties and Methods. http://eprints.ncrm.ac.uk/796/1/discourse_analysis_NCRM_014.pdf

Gottweis, H. (2006). Rhetoric in Policy Making: Between Logos, Ethos, and Pathos. In F. Fischer (Ed.), Handbook of Public Policy (p. 243). London: Taylor and Francis. http://dx.doi.org/10.1201/9781420017007.ch17

Hua, J. Y. (2010). Yu Jinyong’s Claiming for Making a Lawsuit. China New Express Daily, 4 August.

Jiao, L. K. (2011). The Monopoly of “Liang Tong Oil” Elbowing out Private Distributors. Beijing Evening News, 24 October. 
Liu, R. W. (2010). Creating Conditions to Eliminate Death Penalty for Those Corruption Criminals. Economic Information Daily, 21 September.

Piñuel, J. L., \& Gaitán, J. A. (2010). Study of the Hegemonic Discourse about Truth and Communication in the Media’s Self-Referential Information, Based on the Analysis of the Spanish Press.

http://www.revistalatinacs.org/10/art3/920_Complutense/42_PinuelEN.html

Shen, W. Q. (2010). That He Can Cheat All the People Succeeds. New Beijing Daily, 13 July.

Sun, L. Z. (2010). Administrative Accountability in the Form of Praise and Honor. Xinhua Daily Telegraph, 23 October.

Wang, Y. C. (2011). The Rupture between the Official and Civilian Discourses Observed from a Government's Brutal Microblogs. http://views.ce.cn/view/ent/201105/17/t20110517 22424288.shtm

Xiao, Z. X. (2012). Mindset of Ship Abandonment Suffusing China from the Lower to the Upper. The Economic Observer Newspaper, 12 February. 